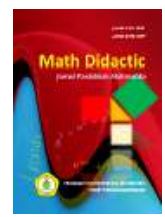

MATH DIDACTIC: JURNAL PENDIDIKAN MATEMATIKA

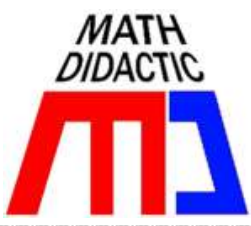

\title{
EFEKTIVITAS MODEL PEMBELAJARAN KOOPERATIF TIPE THINK PAIR SHARE (TPS) DAN NUMBERED HEAD TOGETHER (NHT) BERBANTUAN CD PEMBELAJARAN TERHADAP HASIL BELAJAR MATEMATIKA
}

\section{THE EFFECTIVENESS OF COOPERATIVE LEARNING MODELS THINK PAIR SHARE (TPS) AND NUMBERED HEAD TOGETHER (NHT) USE COMPACT DISK ON RESULTS MATHEMATIC LEARNING}

\author{
Dhestha Hazilla Aliputri, Bambang Suteng Sulasmono, Eunice Widyanti Setyaningtyas \\ Universitas Kristen Satya Wacana \\ 292015073@student.uksw.edu, sulasmonobambang@yahoo.com, eunice.widyanti@uksw.edu
}

\begin{abstract}
Abstrak: Tujuan dari penelitian ini untuk mengetahui efektifitas model pembelajaran kooperatif tipe Numbered Head Together (NHT) dan Think Pair Share (TPS) untuk kemudian dibandingkan model pembelajaran yang lebih efektif ditinjau dari hasil belajar. Penelitian ini terdiri dari dua tahap yaitu pre-test dan post-test. Subjek penelitian ini adalah siswa kelas IV SD N 1 Wulung Kecamatan Randublatung Kabupaten Blora. Berdasarkan hasil penelitian ini diketahui bahwa penggunaan model pembelajaran Numbered Head Together (NHT) lebih efektif daripada Think Pair Share (TPS) ditinjau dari hasil belajar Matematika. Hal ini dapat dilihat dari hasil uji analisis data yang diperoleh hasil bahwa nilai Asymp. Sig. (2-tailed) adalah 0,029 maka 0,029<0,05 sehingga Ho ditolak dan Ha diterima. Dapat disimpulkan bahwa model pembelajaran di kelas eksperimen menggunakan model pembelajaran Numbered Head Together (NHT) lebih efektif daripada penggunaan Think Pair Share (TPS) di kelas kontrol.
\end{abstract}

Kata Kunci: Efektivitas, Matematika, NHT, TPS.

\begin{abstract}
The purpose of this study was to determine the effectiveness of the cooperative learning model Numbered Head Together (NHT) and Think Pair Share (TPS) to compare which one the useful model in terms of learning outcomes. This study consisted of two stages, namely pre-test and post-test. The subjects of this study were fourthgrade students of SD N 1 Wulung District of Randublatung, Blora Regency. Based on the results of this study it was found that the use of NHT learning model was more effective than TPS in terms of Mathematics learning outcomes. This conclusion can be seen from the results of the analysis of data obtained by the results of the value of Asymp. Sig. (2-tailed) is 0.029 then 0.02950 .05 so Ha is rejected and Ho is accepted. It can be concluded that the learning model in the experimental class using NHT learning model is more effective than using TPS in the control class.
\end{abstract}

Keywords: Effectiveness, Mathematics, NHT, TPS.

Cara Sitasi: Aliputri, D.H., Sulasmono, B.S., \& Setyaningsih, E.W. (2019). Efektivitas model pembelajaran kooperatif tipe Think Pair Share (TPS) dan Numbered Head Together (NHT) berbantuan CD pembelajaran terhadap hasil belajar matematika. Math Didactic: Jurnal Pendidikan Matematika, 5(1), 23-31. https://doi.org/10.33654/math.v5i1.498

Submitted: March 15th, 2019

Revised: April 9th, 2019

Published: April 30th, 2019

Available Online Since: April 16th, 2019 
Matematika merupakan salah satu mata pelajaran yang mempunyai peranan penting dalam dunia pendidikan. Matematika diberikan kepada semua jenjang pendidikan dari Sekolah Dasar, Sekolah Menengah Pertama, Sekolah Menengah Atas bahkan Perguruan Tinggi. Matematika merupakan suatu ilmu pengetahuan dengan pola berpikir sistematis, kritis, logis, dan konsisten, serta menuntut daya kreatif dan inovatif. Matematika disusun dari fenomena nyata untuk memecahkan masalah dalam situasi nyata atau masalah yang biasa kita temui dalam kehidupan sehari-hari. Matematika juga merupakan suatu ilmu yang bisa menjadi alat bantu untuk memecahkan ilmu lain. Pola berpikir dalam Matematika yang sistematis, kritis, logis dan cermat menyebabkan mata pelajaran ini dianggap sulit bagi peserta didik yang mempelajarinya (Martono dan Nanang, 2011, hal.vi).

Seperti yang dijelaskan dalam Departemen Pendidikan Nasional (2006) bahwa pendidikan di Sekolah Dasar bertujuan untuk: (1) mendidik siswa agar menjadi manusia Indonesia seutuhnya berdasarkan Pancasila yang mampu membangun dirinya sendiri serta ikut bertanggung jawab terhadap pembangunan bangsa; (2) memberi bekal kemampuan yang diperlukan bagi siswa untuk melanjutkan pendidikan dalam tingkat yang lebih tinggi; dan (3) memberi bekal kemampuan dasar untuk hidup di masyarakat dan mengembangkan diri sesuai dengan bakat, minat, kemampuan dan lingkungannya. Jika dikaitkan dengan konteks pembelajaran matematika maka tujuan pendidikan matematika di sekolah dasar yaitu agar peserta didik memiliki pengetahuan nilai, sikap dan kemampuan untuk mendekatkan dirinya dengan lingkungan sosial, lingkungan alam, lingkungan budaya sehingga pengalaman belajar matematika dapat mereka implementasikan dalam kehidupan sehari-hari. Kendala yang dihadapi guru dalam proses belajar Matematika adalah sebagian besar guru yang mengajar Matematika mengalami kesulitan dalam pelaksanaan pengajaran Matematika, diantaranya disebabkan karena guru kurang memiliki wawasan luas tentang materi-materi Matematika, kurang media pembelajaran dan guru masih menggunakan metode pembelajaran konvensional sehingga peserta didik kurang mampu menerima materi/konsep dengan baik (Hasmiana, 2015, hal. 40).

Peneliti menduga model pembelajaran yang selama ini belum efektif dan menjadi masalah yang menyebabkan hasil belajar Matematika masih rendah. Maka untuk meningkatkan hasil belajar dalam pembelajaran diperlukan model pembelajaran yang melibatkan adanya interaksi antara peserta didik dengan peserta didik lain maupun antara peserta didik dengan guru. Model pembelajaran kooperatif menjadi salah satu model pembelajaran yang mengutamakan kerjasama. Model pembelajaran kooperatif dapat merubah peran guru dari yang pembelajaran terpusat pada guru (Teachercentered) menjadi pembelajaran yang berpusat pada siswa (Student centered). Sehingga guru yang sebelumnya menggunakan model pembelajaran konvensional yang monoton akan berkurang dan beralih pada siswa yang mampu menyelesaikan permasalahan dengan adanya kerjasama dengan peserta didik lain. Sehingga dengan diterapkannya model pembelajaran kooperatif ini peserta didik mampu terlibat aktif dalam proses pembelajaran dan peserta didik tidak cenderung pasif.

Model pembelajaran kooperatif yang dapat digunakan dalam pembelajaran 
Matematika diantaranya model pembelajaran Numbered Head Together (NHT) dan model pembelajaran Think Pair Share (TPS). Dalam beberapa penelitian, kedua model pembelajaran tersebut berhasil meningkatkan hasil belajar Matematika. Seperti halnya penelitian yang dilakukan oleh Pratiwi Ulva yang berjudul Penerapan Model Number Head Together (NHT) dengan Media Flashcard dalam Peningkatan Pembelajaran Matematika Siswa Kelas IV. Dari penelitian tersebut, menyatakan bahwa model pembelajaran Numbered Head Together (NHT) dapat meningkatkan hasil belajar Matematika. Model pembelajaran kooperatif tipe Think Pair Share juga merupakan model pembelajaran yang dapat meningkatkan hasil belajar peserta didik, dimana hal ini sesuai dengan penelitian yang dilakukan Khodir yang berjudul Upaya Meningkatkan Hasil Belajar Perkalian Cara Susun Pelajaran Matematika dengan Model Think Pair And Share (TPS) Pada Siswa Kelas IV. Dalam pembelajaran Matematika dengan menggunakan model pembelajaran kooperatif tipe Numbered Head Together (NHT) setiap siswa akan saling bertukar pikiran dan harus mampu menjawab soal sesuai dengan nomor. Semua anggota harus mampu mengetahui dan menyelesaikan semua soal yang diberikan guru. Sedangkan model pembelajaran tipe Think Pair Share (TPS) memberikan kesempatan kepada peserta didik untuk bekerja sendiri serta bekerja sama dengan orang lain.

Menurut Lie (2010, hal. 59) pengertian Numbered Head Together (NHT) adalah suatu tipe pembelajaran kooperatif yang memberikan kesempatan kepada siswa untuk saling membagikan ide-ide dan mempertimbangkan jawaban yang paling tepat. Selain itu Numbered Head Together (NHT) juga mendorong siswa untuk meningkatkan semangat mereka. Langkahlangkah pembelajaran model pembelajaran Numbered Head Together (NHT) menurut (Trianto, 2009, hal. 82) adalah sebagai berikut:(1)Penomoran (Numbering) Guru membagi siswa ke dalam kelompok 3-5 kelompok dan setiap anggota kelompok dibagikan nomor kepala yang berbeda, (2) Mengajukan Pertanyaan (Questioning) yaitu guru mengajukan beberapa pertanyaan yang harus dijawab oleh tiap-tiap kelompok. Berikan kesempatan kepada tiap-tiap kelompok menemukan jawaban, (3) Berpikir Bersama (Heads Together) yaitu pada tahap ini tiap-tiap kelompok menyatukan kepalanya "Heads Together" berdiskusi memikirkan jawaban atas pertanyaan dari guru, (4) Menjawab Pertanyaan (Answering) yaitu guru memanggil siswa yang memiliki nomor yang sama dari tiap-tiap kelompok. Mereka diberi kesempatan memberi jawaban atas pertanyaan yang telah diterimanya dari guru. Hal itu dilakukan terus hingga semua siswa dengan nomor yang sama dari masingmasing kelompok mendapat giliran memaparkan jawaban atas pertanyaan dari guru.

Menurut (Trianto, 2010, hal. 81) model pembelajaran Think Pair Share (TPS) adalah strategi diskusi, model pembelajaran ini memberikan kesempatan pada siswa untuk bekerja sendiri serta bekerja sama dengan orang lain. Model pembelajaran ini juga memberikan kesempatan pada siswa untuk dapat di kenali dan menunjukkan hasil mereka dengan membagikan hal yang telah siswa dapatkan. Model pembelajaran Think Pair Share (TPS) memberikan kesempatan pada siswa untuk saling membantu satu sama lain dalam menyelesaikan masalah yang telah diberikan oleh guru. Menurut (Atik, 2007, hal. 5) menyatakan karakteristik model kooperatif 


\section{Metode Penelitian}

utama yang dilaksanakan dalam proses pembelajaran, yaitu langkah Think (berpikir secara individu), pair (berpasangan) dan share (berbagi). Secara rinci dapat diuraikan sebagai berikut:(1) Think (berpikir) pada tahap think, guru mengajukan suatu pernyataan atau masalah yang dikaitkan dengan pembelajaran, siswa ditugasi untuk berpikir secara mandiri mengenai pertanyaan atau masalah yang diajukan,

Pair (berpasangan) langkah kedua ini guru menugasi siswa untuk berpasangan dan diskusikan mengenai apa yang telah mereka pikirkan. Setiap pasangan siswa saling berdiskusi mengenai hasil jawaban mereka sebelumnya sehingga hasil yang didapat menjadi lebih baik karena siswa mendapat tambahan informasi dan pemecahan masalah yang lain, (3)Share (berbagi) pada langkah akhir ini guru menugasi pasangan-pasangan tersebut untuk berbagi hasil pemikiran mereka dengan pasangan yang lain atau dengan seluruh kelas. Langkah share (berbagi) merupakan penyempurnaan dari langkah-langkah sebelumnya, dalam arti bahwa langkah ini menolong semua kelompok untuk menjadi lebih memahami mengenai pemecahan masalah yang diberikan berdasarkan penjelasan kelompok lain.

Oleh karena itu dalam permasalahan tersebut peneliti tertarik untuk melakukan suatu penelitian di sekolah dengan membandingkan keefektivitasan dua model terhadap hasil belajar Matematika peserta didik. Model yang digunakan peneliti yaitu model pembelajaran kooperatif tipe Think Pair Share (TPS) dengan Number Head Together (NHT) untuk kemudian diketahui model pembelajaran mana yang lebih efektif ditinjau dari hasil belajar Matematika.
Jenis penelitian ini adalah jenis penelitian eksperimen semu (quasieksperimental research). Manipulasi variabel dalam penelitian ini dilakukan pada variabel bebas yaitu pembelajaran Matematika dengan model pembelajaran Numbered Head Together (NHT) pada kelas eksperimen dan dengan model Pembelajaran Think Pair Share (TPS) pada kelas kontrol. Penelitian ini menggunakan desain- $\mathrm{F}$ atau desain faktorial yang dapat menyelidiki pengaruh dari dua atau lebih variabel yang digunakan. Dalam penelitian ini dapat dilihat perbedaan efektvitas model pembelajaran kooperatif tipe Think Pair Share (TPS) dan model pembelajaran Numbered Head Together (NHT) setelah diberikan treatment dan masingmasing model dapat dilihat manakah yang lebih efektif antara kedua model tersebut.

Subjek dalam penelitian ini adalah siswa kelas IV SD N 1 Wulung Kecamatan Randublatung Kabupaten Blora Semester II Tahun pellajaran 2018/2019. Pada kelas IV terdapat kelas paralel yaitu kelas IVA sebagai kelas eksperimen dan kelas IVB sebagai kelas kontrol. Berikut adalah data jumlah siswa di kelas IV SDN 1 Wulung:

Tabel 1. Data Jumlah Siswa Kelas IV

\begin{tabular}{c|c|c}
\hline Nama Sekolah & Kelas & $\begin{array}{l}\text { Jumlah } \\
\text { siswa }\end{array}$ \\
\hline SDN 1 & IV A & 26 \\
\cline { 2 - 3 } Wulung & IV B & 27 \\
\hline \multicolumn{2}{c}{ Jumlah Keseluruhan } & $\mathbf{5 3}$ \\
\hline
\end{tabular}

Teknik pengumpulan data yang digunakan yaitu dengan soal tes dengan bentuk soal pilihan ganda dengan jumlah 15 butir. Instrumen yang digunakan dalam penelitian ini berupa soal tes yang mencakup materi mengenai Luas dan Keliling Persegi, Persegi 
Panjang dan Segitiga. Data yang terkumpul diolah secara deskriptif untuk selanjutnya diuji normalitas dan homogenitasnya. Kemudian data dianalisis

dengan Non-parametik Sample $T$ Tes menggunakan Mann-Whitney $U$ dengan bantuan SPSS.

\section{Hasil Penelitian dan Pembahasan}

\section{Hasil}

Penelitian ini dilakukan pada siswa kelas IV SD N 1 Wulung Kabupaten Blora Tahun ajaran 2018/2019. Pada kelas eksperimen diterapkan model pembelajaran Numbered Head Together (NHT) dan di kelas Kontrol diterapkan model Think Pair Share (TPS). Berikut adalah data hasil belajar pretest Matematika di kelas eksperimen dan kelas kontrol yang dapat dilihat pada tabel 2.

Tabel 2. Data Deskriptif Pre-Test Hasil Belajar Matematika Kelas Eksperimen dan Kelas Kontrol

\begin{tabular}{c|c|c|c|c|c}
\multicolumn{6}{c|}{ Descriptive Statistics } \\
\hline & $\mathrm{N}$ & Min & Max & Mean & $\begin{array}{c}\text { Std. } \\
\text { Deviation }\end{array}$ \\
\hline Eksperimen & 26 & 60 & 80 & 7.35 & 6.132 \\
Kontrol & 27 & 60 & 80 & 7.33 & \\
Valid N & 26 & & & & 5.968 \\
(listwise) & 26 & & & & \\
\hline
\end{tabular}

Dari tabel diatas dapat dilihat bahwa hasil belajar Matematika pada kelas eksperimen dengan jumlah data $(\mathrm{N})$ sebanyak 26 mempunyai nilai minimum 60 dan nilai maximum 80. Rata-rata/mean di kelas eksperimen yaitu 67,35 dengan standar deviation 6,132. Sedangkan hasil belajar dengan di kelas kontrol mempunyai nilai minimum 60 dan nilai maximum 80 . Rata- rata/mean di kelas kontrol sebesar 67,33 dengan nilai standar deviation sebesar 5,968. Dari tabel diatas dapat dilihat adanya perbedaan mean/rata-rata skor hasil belajar post test yaitu 0,02 . Selanjutnya akan disajikan data hasil uji decriptif statistic hasil belajar Matematika Post-Test di kelas eksperimen dan kelas kontrol yang dapat dilihat dalam tabel 3 .

Tabel 3. Data Deskriptif Statistic

Post- Test Kelas Eksperimen dan Kelas Kontrol.

\begin{tabular}{|c|c|c|c|c|c|}
\hline \multicolumn{6}{|c|}{ Descriptive Statistics } \\
\hline & $\mathrm{N}$ & Min & Max & Mean & $\begin{array}{l}\text { Std. } \\
\text { Deviation }\end{array}$ \\
\hline Eksperimen & 26 & 73 & 100 & 83.58 & 7.044 \\
\hline Kontrol & 27 & 73 & 100 & 80.33 & 8.110 \\
\hline $\begin{array}{l}\text { Valid } \\
\text { (listwise) }\end{array}$ & 26 & & & & \\
\hline
\end{tabular}

Dari tabel diatas dapat dilihat bahwa hasil belajar Matematika pada kelas eksperimen dengan jumlah data $(\mathrm{N})$ sebanyak 26 mempunyai nilai minimum 73 dan nilai maximum 100. Rata-rata/mean di kelas eksperimen yaitu 83,58 dengan standar deviation 7.044. Sedangkan hasil belajar dengan di kelas kontrol mempunyai nilai minimum 73 dan nilai maximum 100. Ratarata/mean di kelas kontrol sebesar 80,33 dengan nilai standar deviation sebesar 8,110. Dari tabel diatas dapat dilihat adanya perbedaan mean/rata-rata skor hasil belajar post test yaitu 3,25.

Sebelum dilakukan analisis data, terlebih dahulu peneliti melakukan uji normalitas dan uji homogenitas. Uji normalitas tersaji pada tabel 4. Berdasarkan tabel 3 terlihat bahwa sampel dari tiap kelompok data memiliki nilai Sig. $<0,05$ maka dapat disimpulkan bahwa semua kelompok data hasil belajar Matematika di 
kelas eksperimen dan kelas kontrol berdistribusi tidak normal.

Tabel 4. Hasil Uji Normalitas Tests of Normality

\begin{tabular}{|c|c|c|c|c|c|c|}
\hline & \multicolumn{3}{|c|}{$\begin{array}{l}\text { Kolmogorov- } \\
\text { Smirnov }^{\mathrm{a}}\end{array}$} & \multicolumn{3}{|c|}{ Shapiro-Wilk } \\
\hline & $\begin{array}{c}\text { Statist } \\
\text { ic }\end{array}$ & df & Sig. & Statistic & Df & Sig. \\
\hline $\begin{array}{c}\text { kelas_eksper } \\
\text { imen }\end{array}$ & .241 & 26 & .000 & .866 & 26 & 003 \\
\hline kelas_kontro & .222 & 26 & .002 & .847 & 26 & 001 \\
\hline
\end{tabular}

Hasil pengujian homogenitas terhadap hasil belajar Matematika di kelas eksperimen dan kelas kontrol dapat dilihat pada tabel 5 . Berdasarkan tabel 5 Tabel diatas mendeskripsikan hasil uji homogenitas nilai pretest di kelas eksperimen dan kelas kontrol. Dari data diatas dapat dilihat bahwa nilai signifikan $\mathrm{Sig}>0,05$. Sehingga dapat disimpulkan bahwa data pretest di kelas eksperimen dan kelas kontrol bersifat homogen.

Tabel 5. Hasil uji Homogenitas Kelas Eksperimen dan Kelas Kontrol

Test of Homogeneity of Variances

\begin{tabular}{c|c|c|c}
\hline Levene Statistic & $\mathrm{df1}$ & $\mathrm{df2}$ & Sig. \\
\hline .283 & 2 & 22 & .756 \\
\hline
\end{tabular}

Dikarenakan berdasarkan uji normalitas dan homogenitas data hasil belajar di kelas eksperimen dan kelas kontrol berdistribusi tidak normal dan homogen maka uji analisis yang digunakan yaitu uji nonparametik menggunakan Mann-Whitney U. Sebelum dilakukan uji analisis terlebih dahulu peneliti melakukan uji hipotesis pertama untuk mengetahui pengaruh model pembelajaran
Numbered Head Together (NHT) di kelas eksperimen yang dapat dilihat pada tabel 6 .

\section{Tabel 6. Uji Hipotesis 1 Pengaruh Numbered Head Together (NHT) Kelas Eksperimen}

\begin{tabular}{r|l}
\multicolumn{2}{c}{ Test Statistics $^{\mathbf{a}}$} \\
\hline Mann-Whitney U & Nilai \\
Wilcoxon W & 27.500 \\
Z & 378.500 \\
Asymp. Sig. (2-tailed) & 5.787 \\
\hline
\end{tabular}

Berdasarkan tabel diatas, dapat disimpulkan bahwa nilai Asymp. Sign.(2 tailed $)=0,000<0,05$ maka Ho ditolak dan $\mathrm{Ha}$ diterima, sehingga dapat ditarik kesimpulan terdapat perbedaan rata-rata pre test dan post test maka model pembelajaran Numbered Head Together (NHT) mempunyai pengaruh terhadap hasil belajar di kelas eksperimen. Selanjutnya peneliti melakukan uji hipotesis kedua untuk mengetahui pengaruh model pembelajaran Think Pair Share (TPS) di kelas kontrol yang dapat dilihat pada tabel 7.

Tabel 7. Pengaruh Think Pair Share (TPS) kelas Kontrol

Test Statistics ${ }^{\text {a }}$

\begin{tabular}{l|l}
\hline & Nilai \\
\hline Mann-Whitney U & 55.000 \\
Wilcoxon W & 433.000 \\
Z & 5.537 \\
Asymp. Sig. (2-tailed) & .000 \\
\hline
\end{tabular}

Berdasarkan tabel diatas, dapat disimpulkan bahwa nilai Asymp. Sign.(2 tailed $)=0,000<0,05$ maka Ho ditolak dan $\mathrm{Ha}$ diterima, sehingga dapat ditarik kesimpulan terdapat perbedaan rata-rata pre test dan post test maka model pembelajaran Think Pair Share mempunyai pengaruh terhadap hasil belajar di kelas kontrol. Selanjutnya dilakukan 
uji analisis akhir untuk mengetahui model pembelajaran yang lebih efektif antara Numbered Head Together (NHT) dan Think Pair Share (TPS) yang dapat dilihat dalam tabel 8 .

Tabel 8. Hasil Uji Hipotesis Hasil Belajar Matematika Kelas Eksperimen dan Kelas Kontrol

\begin{tabular}{l|l}
\multicolumn{2}{c}{ Test Statistics $^{\mathbf{a}}$} \\
\hline Mann-Whitney U & Nilai \\
Wilcoxon W & 613.000 \\
Z & -2.190 \\
Asymp. Sig. (2-tailed) & .029 \\
\hline
\end{tabular}

Berdasarkan tabel diatas, diperoleh hasil bahwa nilai Asymp. Sig. (2-tailed) adalah 0,029 maka $0,029<0,05$ sehingga Ha ditolak dan Ho diterima. Dapat disimpulkan bahwa model pembelajaran di kelas eksperimen menggunakan model pembelajaran Numbered Head Together (NHT) lebih efektif daripada penggunaan Think Pair Share (TPS) di kelas kontrol.

\section{Pembahasan}

Berdasarkan hasil analisis data yang telah dilakukan dan yang telah disajikan sebelumnya, peneliti menyimpulkan bahwa model pembelajaran Numbered Head Together (NHT) lebih efektif dibandingkan model pembelajaran Think Pair Share (TPS) terhadap hasil belajar Matematika siswa kelas IV SD Negeri 1 Wulung Kabupaten Blora semester II tahun pelajaran 2018/2019. Dalam analisis yang dilakukan menunjukkan bahwa adanya pengaruh penggunaan model pembelajaran Numbered Head Together (NHT) di kelas eksperimen dan Think Pair Share (TPS) di kelas kontrol, untuk kemudian dibandingkan model pembelajaran yang lebih efektif digunakan ditinjau dari hasil belajar Matematika. Media pembelajaran Power Point interaktif yang digunakan dapat membantu untuk menyajikan materi dalam bentuk animasi dan gambar. Materi yang disajikan dalam Power Point interaktif tersebut adalah materi mengenai Luas dan Keliling bangun persegi, persegi panjang, dan segitiga sehingga siswa dapat lebih tertarik dalam mengikuti pembelajaran.

Deskripsi awal skor hasil belajar pre test menunjukkan bahwa rata-rata awal kelas kontrol adalah 67,35 dan rata-rata kelas eksperimen adalah 67,33, dengan nilai terendah dikelas eksperimen dan kontrol adalah 60 dan nilai tertinggi 80. Setelah dilakukan treatment/perlakuan di masingmasing kelas, terlihat adanya peningkatan hasil belajar Matematika di kelas eksperimen dan kelas kontrol. Hal ini dapat ditunjukkan dari adanya peningkatan rata-rata hasil belajar antara pre test dan post test. Rata-rata hasil belajar awal kelas eksperimen yaitu 67,35 setelah dilakukan treatment/perlakuan, ratarata pada kelas eksperimen meningkat menjadi 83,58 atau terjadi peningkatan 16,23point. Nilai terendah dan nilai tertinggi yang pada pretest di kelas eksperimen yaitu 60 dan 80 setelah dilakukan treatment/perlakuan meningkat menjadi 73 dan 100. Peningkatan juga terjadi di kelas kontrol, dimana rata-rata awal hasil belajar Matematika yaitu 67,33 setelah dilakukan treatment/perlakuan, ratarata hasil belajar meningkat menjadi 80,33 atau terjadi peningkatan 13 point. Nilai terendah dan nilai tertinggi yang pada pretest di kelas eksperimen yaitu 60 dan 80 setelah dilakukan treatment/perlakuan meningkat menjadi 73 dan 100.

Pada Group Statistic terliha rata-rata (mean) untuk kelas eksperimen adalah 83,58 dan untuk kelas kontrol adalah 80,33, artinya 
rata-rata skor hasil belajar Matematika di kelas eksperimen lebih tinggi dari rata-rata skor hasil belajar Matematika kelas kontrol dengan perbedaan rata-rata (mean deference) adalah 3,25 .

Uji hipotesis pertama menunjukkan bahwa penerapan model pembelajaran Numbered Head Together mempunyai pengaruh terhadap hasil belajar Matematika di kelas eksperimen. Hal ini dapat dilihat dari hasil uji hipotesis yang menunjukkan nilai Asymp. Sign. $(2$ tailed $)=0,000<0,05$ maka Ho ditolak dan Ha diterima, sehingga dapat ditarik kesimpulan terdapat perbedaan rata-rata pre test dan post test maka model pembelajaran Numbered Head Together mempunyai pengaruh terhadap hasil belajar di kelas eksperimen. Kemudian peneliti melakukan hipotesis kedua untuk melihat ada atau tidaknya pengaruh model pembelajaran Think Pair Share di kelas kontrol. Hasil uji hipotesis kedua menunjukkan adanya pengaruh model pembelajaran Think Pair Share terhadap hasil belajar Matematika. Berdasarkan tabel hasil uji hipotesis kedua, dapat dilihat bahwa nilai Asymp. Sign. $(2$ tailed $)=0,000<0,05$ maka Ho ditolak dan Ha diterima, sehingga dapat ditarik kesimpulan terdapat perbedaan rata-rata pre test dan post test maka model pembelajaran Think Pair Share mempunyai pengaruh terhadap hasil belajar di kelas kontrol.

Pada uji hipotesis ketiga atau uji hipotesis terakhir, peneliti akan memperoleh data model pembelajaran manakah yang lebih efektif ditinjau dari hasil belajar post test di kelas eksperimen dan kelas kontrol. Diperoleh hasil bahwa nilai Asymp. Sig. (2-tailed) adalah 0,029 maka $0,029<0,05$ sehingga Ho ditolak dan Ha diterima. Dapat disimpulkan bahwa model pembelajaran di kelas eksperimen menggunakan model pembelajaran Numbered Head Together (NHT) lebih efektif daripada penggunaan Think Pair Share (TPS) di kelas kontrol.

Hal ini menunjukkan bahwa model pembelajaran Numbered Head Together (NHT) sesuai pendapat (Lie, 2010, hal. 59) Dalam pembelajaran menggunakan model pembelajaran Numbered Head Together (NHT) setiap siswa dalam kelompok diberikan nomor kepala agar setiap siswa dalam kelompok itu siap sehingga siswa dalam kelompok harus mengerti atau memahami pemecahan dan masalah yang diberikan, hal itu akan membuat tanggung jawab siswa menjadi lebih besar untuk menyelesaikan masalah yang diberikan. Selain itu peneliti melihat dalam pembelajaran yang telah dilakukan bahwa terdapat antusias yang berbeda dari kelas eksperimen dan kelas kontrol, dimana penerapan model pembelajaran Numbered Head Together (NHT) di kelas eksperimen terlihat lebih kondusif karena siswa merasa senang dengan pemberian nomor kepala dan lebih bersemangat karena soal/pertanyaan dikerjakan bersama-sama dalam kelompok. Berbeda dengan penerapan model pembelajaran Think Pair Share (TPS) di kelas kontrol, siswa terlihat lebih pasif dan kurang bersemangat dalam mengerjakan soal/pertanyaan yang diberikan karena hanya dikerjakan secara berpasangan/berdua sesuai dengan kartu soal yang mereka dapatkan. Model pembelajaran Numbered Head Together bisa digunakan sebagai salah satu alternatif yang dapat diterapkan sebagai dasar pelaksanaan kegiatan pembelajaran Matematika di sekolah dasar. 


\section{Simpulan dan Saran}

\section{Simpulan}

Hasil penelitian ini menunjukkan bahwa setelah analisis data pada uji hipotesis terakhir yang dilakukan dengan Non-parametik sample t Test diketahui bahwa nilai Asymp. Sig. (2tailed) adalah 0,029 maka 0,029 $<0,05$ sehingga Ho ditolak dan $\mathrm{Ha}$ diterima. Sehingga dari hasil tersebut diketahui bahwa hasil belajar Matematika menggunakan model pembelajaran Numbered Head Together (NHT) lebih efektif dari model pembelajaran Think Pair Share (TPS) di kelas IV SDN Wulung 1 Kecamatan Randublatung Kabupaten Blora Semester II Tahun Pelajaran 2018/2019.

\section{Saran}

Berdasarkan hasil penelitian yang dilakukan, maka ada beberapa saran yang ditunjukkan kepada: (1) Bagi Sekolah, dalam usaha meningkatkan hasil belajar siswa diperlukan model pembelajaran yang lebih variatif/bervariasi. Model pembelajaran Numbered Head Together (NHT) atau Think Pair Share(TPS) dapat digunakan sebagai variasi model pembelajaran yang dapat dipergunakan, (2) Bagi Guru, guru dapat menggunakan model pembelajaran Numbered Head Together (NHT) sebagai alternatif kegiatan belajar-mengajar di kelas.

\section{Daftar Pustaka}

Atik Widarti. (2007). Efektifitas Penggunaan Model Pembelajaran Kooperatif Tipe Think Pair Share Terhadap Hasil Belajar Pokok Bahasan Segi Empat pada Siswa Kelas VII. Skripsi. UNNES.
Hasmiana Hasan, (2015). Kendala yang Dihadapi Guru Dalam Pembelajaran, PESONA DASAR: Jurnal Pendidikan Dasar dan Humaniora, 1, 40-51, 23379227.

Khodir, M. A. (2011). Upaya Meningkatkan Hasil Belajar Perkalian Cara Susun Pelajaran Matematika dengan Model Think Pair And Share (TPS) Pada Siswa Kelas IV SDN Plumbungan Gabus Kabupaten Pati Semester I Tahun 2011/2012 (Doctoral dissertation, Program Studi Pendidikan Guru Sekolah Dasar PSKGDJ FKIP-UKSW).

Martono, Nanang. (2011). Metode Penelitian Kuantitatif. Jakarta: PT Raya Grafindo Persada.

Nasional, D. P. (2006). Kurikulum tingkat satuan pendidikan.

Lie. (2010). Cooperative Learning. Jakarta: Grasindo.

Pratiwi, U. (2015). Penerapan Model Number Head Together dengan Media Flashcard dalam Peningkatan Pembelajaran Matematika Siswa Kelas IV SD Negeri 3 Dorowati Tahun Ajaran 2014/2015. KALAM CENDEKIA PGSD KEBUMEN, 3(5.1).

Trianto. (2007). Model-model Pembelajaran Inovatif Berorientasi Konstruktivistik. Jakarta: Prestasi Pustaka. 